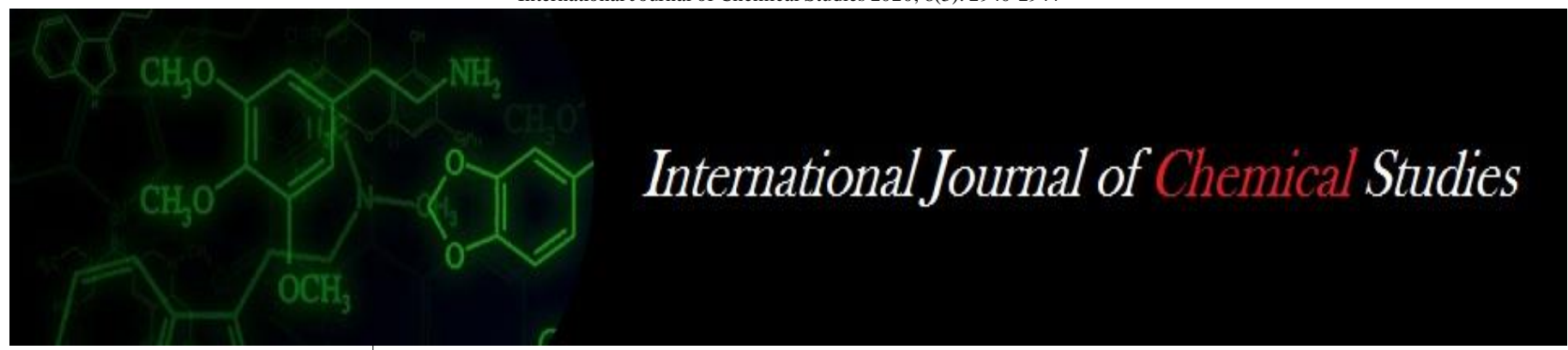

P-ISSN: 2349-8528

E-ISSN: 2321-4902

www.chemijournal.com

IJCS 2020; 8(3): 2940-2944

(C) 2020 IJCS

Received: 04-03-2020

Accepted: 06-04-2020

\section{SU Kakade}

All India Coordinated Research Project on Weed Management, Department of Agronomy, Dr. Panjabrao Deshmukh Krishi

Vidyapeeth, Akola,

Maharashtra, India

\section{JP Deshmukh}

All India Coordinated Research Project on Weed Management, Department of Agronomy, Dr. Panjabrao Deshmukh Krishi

Vidyapeeth, Akola,

Maharashtra, India

\section{ND Parlawar}

All India Coordinated Research Project on Weed Management, Department of Agronomy, Dr. Panjabrao Deshmukh Krishi

Vidyapeeth, Akola,

Maharashtra, India

\section{RM Indore}

All India Coordinated Research Project on Weed Management, Department of Agronomy, Dr. Panjabrao Deshmukh Krishi

Vidyapeeth, Akola,

Maharashtra, India

\section{SS Thakare}

All India Coordinated Research Project on Weed Management, Department of Agronomy, Dr. Panjabrao Deshmukh Krishi

Vidyapeeth, Akola,

Maharashtra, India
Corresponding Author:

SU Kakade

All India Coordinated Research Project on Weed Management, Department of Agronomy, Dr. Panjabrao Deshmukh Krishi

Vidyapeeth, Akola,

Maharashtra, India

\section{Efficacy of different post-emergence herbicide in chickpea (Cicer arietinum $\mathbf{L}$.)}

\author{
SU Kakade, JP Deshmukh, ND Parlawar, RM Indore and SS Thakare
}

DOI: https://doi.org/10.22271/chemi.2020.v8.i3aq.9656

\begin{abstract}
A field experiment entitled "Efficacy of different post-emergence herbicide in chickpea (Cicer arietinum L.)" was carried out at the farm of AICRP on Weed Management, Department of Agronomy, Dr. Panjabrao Deshmukh Krishi Vidyapeeth, Akola, during Rabi season 2016-17.The investigation was carried out to study the relative efficacy of post emergence herbicides on weed control in chickpea, as well as to study the phytotoxic effect on crop, growth and yield of chickpea. The experiment was laid out in Randomized Block Design with eleven treatments replicated thrice. The treatment comprised of different post-emergence herbicides in different doses and were compared with the cultural methods. The soil of experimental was fairly uniform and levelled and low in available nitrogen, and organic carbon, medium in phosphorus, rich in available potassium and slightly alkaline in reaction. Chickpea (JAKI9218) was sown on $11^{\text {th }}$ Nov 2016 at $30 \times 10 \mathrm{~cm}$ spacing with fertilizer dose of 25:50:30 NPK kg/ha. The results revealed that, among the various treatments under study, weed free treatment (2Hand Weeding) recorded significantly higher values of major parameters whereas, in herbicidal treatments, the maximum growth and yield attributes were recorded with treatment of Oxyflourfen@ $150 \mathrm{~g}$ a.i./ha as a post emergence application at 40 DAS which was at par with treatment Imazethapyr 10\% @ $50 \mathrm{~g}$ a.i./ha. Among the post emergence herbicides, reduction in weed density, weed dry matter, higher weed control efficiency $(84.31 \%)$ and lowest weed index $(5.07 \%)$ was found with Oxyflourfen @ $150 \mathrm{~g}$ a.i./ha POE 40 DAS and higher weed index in weedy check (45.90\%). Oxyflourfen @ $150 \mathrm{~g}$ a.i./ha POE 40 DAS was found most economical with maximum value of GMR (88358 Rs ha-1), NMR(58884 Rs ha- ${ }^{-1}$ ) and B: C ratio (3.00). The net return per hectare was more under cultural practice i.e. two hand weeding at 30 and 50 DAS but the difference was not much when compared to effective post emergence herbicide (Oxyflurofen@150g/ha).
\end{abstract}

Keywords: Chickpea, hand weeding, weeds, oxyflurofen, post-emergence

\section{Introduction}

The Chickpea (Cicer arietinum) is one of the most important pulse crops of India grown both under conserved soil moisture and irrigated situations. It is very good source of carbohydrates and proteins which altogether constitute about $80 \%$ of the total dry seed weight. Its leave secretes malic acid (90-95\%) and oxalic acid (5-10\%) which have medicinal importance against stomach ache, intestinal disorder and blood purification. In India, chickpea has the highest area and production in the year 2018-19. It is cultivated over an area of 81.17 lakh producing 59.01 lakh tones with an average productivity of $727 \mathrm{~kg} / \mathrm{ha}$. Maharashtra ranks $2^{\text {nd }}$ in area and production after Madhya Pradesh. In Maharashtra it constitutes about 17.74 lakh hectare area producing 15.07 lakh tones with productivity of $850 \mathrm{~kg} / \mathrm{ha}$.

Chickpea is a poor competitor of weeds because of slow growth rate and limited leaf area during development at early stages of crop growth (30-45 DAS). In addition to slow initial crop growth. Mukherjee (2007) ${ }^{[11]}$ reported 30-54\% losses in chickpea production caused due to weeds. Weeds are the major problem in irrigated chickpea also. Many research workers reported the predominance of Avena ludoviciana, Chenopodium album, Cynodon dactylon, Phalaris minor and Medicago hispida, Anagali sarvensis, Melilotusindica, Melilotusalba, Cyperus rotundus, Argemone maxicana, Solanum nigrum, Vicia hirsute and Vicia sativa weeds in chickpea field (Gupta et al., 2012) ${ }^{[5]}$. The high cost and unavailability of labour at right time sometimes compel the farmer for opting alternative, cheaper and easier method of chemical weed control. Weed emergence with the rabi sown chickpea crop creates a severe 
competition unless controlled timely and effectively. Only inter-row cultivation is not sufficient to control the weeds, under most of the conditions inter-row hand weeding is also necessary. But controlling the weeds by mechanical method is not beneficial under the certain conditions because mechanical method of controlling the weed is laborious which increases the cost of cultivation. Management of weeds is considered to be an important factor for achieving higher productivity Therefore, there is an urgent need to move from the costly, manual and mechanical weed control to chemical weed control (Marwat et al. 2003) ${ }^{[9]}$. There are various methods used to control weeds in chickpea crop which include manual, mechanical, cultural including crop rotations, crop competition, and chemical. The first two methods are common in the less developed farming systems while the last is dominant in the developed farming system. There is an urgent need for assessing the growth and yield of chickpea under the different weed control treatments of post emergence herbicides. The study will be helpful to see the effect of post emergence herbicides on growth and yield of chickpea. It will beneficial for farmers and also to research worker to carry out the research on the weed management of chickpea. It improves weed control practices that include chemical weed control with newer formulations and herbicides mixtures. The hypothesis is that weeds can be controlled efficiently and yield maintained at lower rate of input practice by the better used management strategy. Keeping in view that the limitation of other weed control methods for weed management in chickpea, the use of different post emergence herbicides will be effective and economical for broad spectrum weed control in chickpea. As till date no post emergence herbicide is recommended under label claim in chickpea crop and phototoxic effect of some post emergence herbicides are seen in chickpea crop. Therefore, the present investigation was planned with a objective to study the efficacy of post emergence herbicides and its effect on weed flora, phytotoxicity on crop, growth, productivity and profitability in chickpea.

\section{Materials and methods}

The present field experiment was conducted during Rabi season of the year 2016-17 at the research farm of AICRPWeed Management, Dr.Panjabrao Deshmukh Krishi Vidyapeeth, Akola(M.S.) in Randomized Block Design with three replication having eleven different treatments of weed management including Quizalofop ethyl 5\%@ $00 \mathrm{~g}$ a.i./ha $\left(\mathrm{T}_{1}\right)$, Quizalofop ethyl 5\% @ $75 \mathrm{~g}$ a.i./ha $\left(\mathrm{T}_{2}\right)$, Imazethapyr 10\%@ $050 \mathrm{~g}$ a.i./ha $\left(\mathrm{T}_{3}\right)$, Oxyflourfen@ $150 \mathrm{~g}$ a.i./ha $\left(\mathrm{T}_{4}\right)$, Imazethapyr 35\% + Imazomox 35\% @ $40 \mathrm{~g}$ a.i./ha $\left(\mathrm{T}_{5}\right)$, Imazethapyr 35\% + Imazomox 35\% @60 g a.i./ha $\left(\mathrm{T}_{6}\right)$, Clodinafop propargyl + Na-aciflurofen 16.5\% @ $300 \mathrm{~g}$ a.i./ha $\left(\mathrm{T}_{7}\right)$, Clodinafop propargyl + Na aciflurofen (16.5\%)@ $500 \mathrm{~g}$ a.i./ha (T8), Propaquizafop 10\% @ 100 g a.i./ha ( $\left.\mathrm{T}_{9}\right)$, Two hand weeding at 30 and 50 DAS. $\left(\mathrm{T}_{10}\right)$ and Weedy-check $\left(\mathrm{T}_{11}\right)$. The soil of experimental field characterized as fairly uniform and levelled. Soil of experimental plot was vertisol. It was low in available nitrogen $(220.58 \mathrm{~kg}$ ha-1) and organic carbon $(0.48 \%)$, medium in phosphorus $\left(17.68 \mathrm{~kg} \mathrm{ha}^{-1}\right)$, rich in available potassium $\left(384.25 \mathrm{~kg} \mathrm{ha}^{-1}\right)$ and slightly alkaline in reaction (7.8). Chickpea (JAKI-9218) was sown on $11^{\text {th }}$ Nov 2016 at $30 \times 10 \mathrm{~cm}$ spacing with fertilizer dose of 25:50:30 NPK kg/ha.

The application of herbicide was done as per the treatments with manually operated knapsack sprayer attached with a flood jet nozzle. After calibrating the sprayer, water volume used was 500 lit. per ha. for post emergence herbicides. The observations on weed density and weed biomass were taken at 20 days interval upto harvest from four randomly selected spots by using a quadrate of $50 \mathrm{~cm}$ x $50 \mathrm{~cm}$ quadrate from net plot area. Then weeds were grouped as monocot species and dicot species. Weed control efficiency (WCE) was calculated by using standard formula suggested by Maity and Mukherjee (2011) ${ }^{[8]}$. Phytotoxicity symptoms due to herbicides on crop was recorded by using a visual score scale of 0-10 scale method as proposed by Rao (2000) ${ }^{[5]}$. Visual assessment of herbicide toxicity on crop was monitored 10 days after application of herbicide in respective treatment. Data on various growth and yield attributing characters were statistically analysed as per the standard procedure.

\section{Results and discussion \\ Weed flora}

Both broad leaf and narrow leaf weeds were observed but dominance of broad leaved weeds was observed in entire field. The major weed flora during rabi season in chickpea crop in the selected area composed Chenopodium album, Euphorbia geniculata, Tridex procumbance, Parthenium hysterophorus, Celosia argentea, Ipomea carnea, Argemone mexicana, Anagall is arvensis among the dicot weeds and cynodon dactylon, cyperus rotundus, amaranthis viridis, dinebra arabica, panicum spp. Cynodon dactylon, Cyperus rotundus, Erogrostis major digitaria sanguinalis, were the major monocot weeds observed in the experimental field. Similar weed flora in chickpea was also reported earlier by Singh et al. (2006) ${ }^{[20]}$ and Ratnam et al. (2011) ${ }^{[16]}$.

\section{Effect on weeds}

The data presented in Tables 1 revealed that the weed control treatments significantly reduced the total (monocot+ dicot) weed population and total dry weed biomass when compared with unweeded control. Initially at 20 DAS non significant differences were observed with regards to weed density and weed dry matter. However 40 DAS onwards upto harvest significantly lowest total weeds density and weed dry matter was recorded in the treatment of cultural practice of two hand weeding at 30 and 50 DAS $\left(\mathrm{T}_{10}\right)$ than rest of the weed management treatments. Among the post emergence herbicidal treatments, Oxyflourfen @ $150 \mathrm{~g}$ a.i./ha $\left(\mathrm{T}_{4}\right)$, produced lower weed count but were statistically at par with treatment Imazethapyr 10\% @ $50 \mathrm{~g}$ a.i./ha $\left(\mathrm{T}_{3}\right)$, Clodinafop propargyl + Na-aciflurofen 16.5\%@ $300 \mathrm{~g}$ a.i./ha $\left(\mathrm{T}_{7}\right)$ and Clodinafop propargyl $+\mathrm{Na}$ aciflurofen (16.5\%) @ $500 \mathrm{~g}$ a.i./ha (T8), Imazethapyr 35\% + Imazomox 35\% @ $40 \mathrm{~g}$ a.i./ha and @.60 g a.i./ha was found at par with each other. The Weedy check $\left(T_{11}\right)$ recorded significantly higher weed population at all the growth stages during the experimentation. At harvest stage, treatment weed free $\left(\mathrm{T}_{10}\right)$ found significantly superior in reducing the total weeds population than rest of the weed management treatments. The post emergence herbicide Oxyflourfen @ $150 \mathrm{~g}$ a.i./ha showed its superiority in lowering down the weed population over all other herbicidal treatments. Total weed density and weed dry biomass was reduced significantly due to various weed control treatments at all stages of crop growth. This might be due to the post emergence herbicides application which was effective in timely reducing total weed population. Similar results regarding weed density and weed dry biomass were also reported by Patel et al. (2006) ${ }^{[12]}$, Rupareliya et al. (2017) ${ }^{[18]}$, Singh et al. (2006) ${ }^{[20]}$ and Ratnam et al. $(2011)^{[16]}$. 
Weed control efficiency of maize was influenced by weed management treatments, where all the cultural and post emergence herbicides treatments resulted in increase of weed control efficiency over the weedy check. The highest weed control efficiency $(85.52 \%)$ was observed in treatment of two hand weeding at 30 and 50 DAS $\left(\mathrm{T}_{10}\right)$ from 20 DAS up to at harvest, because of keeping weed free environment and found superior over rest of all herbicidal treatments. Among the post emergence herbicides at harvest, the highest weed control efficiency (84.31\%) was found in Oxyflourfen @ $150 \mathrm{~g}$ a.i./ha (T4) followed by Clodinafop propargyl $+\mathrm{Na}$ aciflurofen (16.5\%) @ $500 \mathrm{~g}$ a.i./ha (83.66\%) and Imazethapyr 10\% @ $50 \mathrm{~g}$ a.i./ha $(83.53 \%)$. Data on weed index as indicated in Table 2 showed the least yield reduction (5.07\%) with Oxyflourfen @ $150 \mathrm{~g}$ a.i./ha followed by the treatments Imazethapyr 10\% @ $50 \mathrm{~g}$ a.i./ha (9.10\%) and Propaquizafop 10\% @ $100 \mathrm{~g}$ a.i./ha (11.19\%). Whereas yield reduction varied from $5.07 \%$ to $26.67 \%$ in the herbicide applied treatments as compared to weed free treatment. The lower weed index in Clodinafop propargyl + Na-aciflurofen 16.5\%@300 g a.i./ha and @ 500 g a.i./ha was observed due to yield reduction because of severe phytotoxicity of this herbicide on chickpea crop. Weedy check $\left(\mathrm{T}_{11}\right)$ treatment recorded maximum weed index i.e. $45.90 \%$ indicating the reduction in chickpea grain yield due to presence of weeds throughout crop growth period. Lower is the weed index in chemical treatments, better the efficiency of that herbicide in controlling weeds, which provided favorable conditions for crop growth which ultimately increased the grain yield of chickpea crop as compared to weedy check treatment. Similar results were also reported by Chaudhary et al. (2005) ${ }^{[2]}$, Patel and Patel (2006) ${ }^{[12]}$ and Kachhadiya et al. (2009) ${ }^{[6]}$.

\section{Crop Phytotoxicity}

Phtotoxicity symptoms due to herbicide on chickpea crop was recorded by using visual score scale of $0-10$. Visual assessment of herbicide toxicity on crop was monitored 10 days after application of herbicide in respective treatment. The post emergence herbicide Clodinofop propargyl $+\mathrm{Na}$ aciflurofen $16.5 \%$ @ 300 g a.i./ha showed severe phytotoxicity on chickpea crop, however this herbicide controlled most of the weeds. The upper portion of all the chickpea plants were severely injured due to Clodinofop propargyl + Na aciflurofen $16.5 \%$ @ 500 g a.i./ha which results in loss in final crop stand of chickpea. Application of Oxyflourfen @ $150 \mathrm{~g}$ a.i./ha $\left(\mathrm{T}_{4}\right)$, Imazethapyr 35\% + Imazomox 35\%@60 g a.i./ha $\left(\mathrm{T}_{6}\right)$ and Imazethapyr 35\%+ Imazomox 35\% @ $40 \mathrm{~g}$ a.i./ha moderately injured the crop,but recovered thereafter. Application of Imazethapyr 10\%@ $50 \mathrm{~g}$ a.i./ha and Propaquizafop 10\%, @ $100 \mathrm{~g}$ a.i./ha slightly injuried the crop by stunting and discolouration of leaves. Similar results of crop phytotoxicity were also reported by Ratnam et al. (2011) ${ }^{[16]}$ and Lyon and Wilson $(2005)^{[7]}$.

\section{Effect on growth and yield}

Weed management treatments significantly affected the growth and yield attributing characters of chickpea (Table-3). Significantly maximum plant height $(51.82 \mathrm{~cm})$ and plant dry matter $(21.17 \mathrm{~g})$ of chickpea at harvest was recorded in treatment of two hand weeding at 30 and 50 DAS which was at par with post emergence herbicide application of Oxyflourfen@150 g a.i./ha and Imazethapyr 10\%@50 g a.i./ha. Significant reduction in plant height was noticed in unweeded control treatment at harvest which might be due to the fact that weeds suppressed the vegetative growth of plants by the competition between crop and weeds for soil moisture, plant nutrients, solar radiation and space during active growth period. These results are in accordance with the results reported by Ghosheh et al. (2003) ${ }^{[4]}$.

The data of yield attributing characters presented in Table 3 revealed that, the weed control treatments showed significant influence on number of pods per plant, Seed weight/plant and seed idex. Significantly, maximum number of pods per plant (50.53) at harvest was found in hand weeding treatment and among the herbicidal treatments maximum pods were recorded in Oxyflourfen @ $150 \mathrm{~g}$ a.i./ha (49.51 g), Similar trend was observed with regards to seed weight per plant which was found maximum $(11.65 \mathrm{~g})$ in weed free treatment followed by Oxyflourfen @ $150 \mathrm{~g}$ a.i./ha (11.36 g) and Imazethapyr 10\% @ $50 \mathrm{~g}$ a.i./ha $(10.78 \mathrm{~g})$. The different weed control treatments had no significant differences on seed index (100 seed weight).The post emergence application of Clodinafop propargyl + Na-aciflurofen $16.5 \%$ @ $300 \mathrm{~g}$ a.i./ha and Clodinafop propargyl + Na aciflurofen (16.5\%) @ $500 \mathrm{~g}$ a.i./ha showed moderate to severe phytotoxic symptoms which result in unrecoverable damage to crop and lower seed weight plant $^{-1}$, and number of pods per plant due to slightly higher dosage of herbicides and its phytotoxic effect on crop. The lowest yield attributes values were recorded in weedy check. (Table-3). This might be due to better growth of crop because of less crop weed competition under herbicidal treatment that subsequently increased nutrient and moisture availability to the chickpea crop. Similar results were also reported by Reddy et al. (2008) ${ }^{[17]}$ and Chavada et al. (2017) [3].

Different weed control treatments registered significant increase in grain yield of chickpea compared to unweeded control. The Hand weeding twice i.e. 30 and 50 DAS $\left(\mathrm{T}_{10}\right)$ produced significantly highest chickpea yield $\left(2073 \mathrm{~kg} \mathrm{ha}^{-1}\right)$ as compared to other treatments and remain at par with Oxyflourfen@150 g a.i./ha, and Imazethapyr 10\%@50 g a.i./ha followed by treatments Propaquizafop 10\% @ $100 \mathrm{~g}$ a.i./ha and Imazethapyr 35\% + Imazomox 35\% @60 g a.i./ha. Among the herbicides Clodinafop propargyl $+\mathrm{Na}$ aciflurofen (16.5\%) @ $500 \mathrm{~g}$ a.i./ha (T8) registered comparatively lower yield due to less plant population at harvest because of severe phytotoxicity of this herbicide on chickpea crop. Similar results were also reported by Poonia and Pithia (2013), Sharma et al. (2005).Treatment weedy check registered the lowest yield of $1124 \mathrm{~kg} \mathrm{ha}^{-1}$.The application of Oxyflourfen @ $150 \mathrm{~g}$ a.i./ha increased $42.79 \%$ seed yield over the weedy check. Different weed management practices significantly improved the seed yield over weedy check; this might be due to the better weed control associated with decrease in weed population and improvement in yield contributing characters in these treatments. The post emergence herbicides effectively control the different weeds in chickpea result in good weed control efficiency which ultimately results in higher yield. Similar results were reported by Yousefi et al. (2007), Ratnam et al. (2011) ${ }^{[16]}$ and Singh et al. $(2017)^{[20]}$.

\section{Economics of weed control}

As indicated in Table 3, the maximum GMR of Rs. 93120 ha $^{-}$ ${ }^{1}$ and NMR of Rs.59679 ha ${ }^{-1}$ was registered in hand weeding treatment twice at 30 and $50 \mathrm{DAS}$, followed by treatment of Oxyflourfen@150 g a.i./ha. Though the maximum GMR and NMR was registered in hand weeding treatment, but the maximum $\mathrm{B}: \mathrm{C}$ ratio was found with application of 
Oxyflourfen @ 150 g a.i./ha (3.00) which was closely followed by Imazethapyr 10\% @ $50 \mathrm{~g}$ a.i./ha (2.87), This might be owing to good grain yield obtained under these treatments because of better management of weeds. The GMR, NMR, and B: C ratio was lowest in weedy check due to more weed density and lesser yield. The differences in B:C ratio is due to the cost of herbicides and productivity of the crop. Similar results were obtained by Patel and Patel (2006) [12] and Muhammad et al. (2011). (2016) [10]. Though the cultural method of two hand weeding resulted in highest grain yield owing to $85.52 \%$ weed control efficiency but could not found as profitable as herbicidal treatment due to higher expenditure incurred on engaging more labours.

Table 1: Weed density $\left(\mathrm{No} . / \mathrm{m}^{2}\right)$ and weed dry matter $\left(\mathrm{g} / \mathrm{m}^{2}\right)$ as influenced by different weed control treatments in Chickpea

\begin{tabular}{|c|c|c|c|c|c|c|c|c|c|c|}
\hline \multirow[b]{2}{*}{ Treatments } & \multicolumn{5}{|c|}{ Total weed density (No./m2) } & \multicolumn{5}{|c|}{ Weed dry matter (g/m2) } \\
\hline & $\begin{array}{c}20 \\
\text { DAS }\end{array}$ & \begin{tabular}{|c|}
40 \\
DAS
\end{tabular} & $\begin{array}{c}\text { 60 } \\
\text { DAS }\end{array}$ & \begin{tabular}{c|} 
80 \\
DAS
\end{tabular} & $\begin{array}{c}\text { At } \\
\text { harvest }\end{array}$ & $\begin{array}{c}20 \\
\text { DAS }\end{array}$ & $\begin{array}{c}40 \\
\text { DAS }\end{array}$ & \begin{tabular}{|c|}
60 \\
DAS
\end{tabular} & \begin{tabular}{|c|} 
80 \\
DAS
\end{tabular} & $\begin{array}{c}\text { At } \\
\text { harvest }\end{array}$ \\
\hline $\mathrm{T}_{1}$ - Quizalofop ethyl 5\% @ $50 \mathrm{~g}$ a.i./ha. & $\begin{array}{c}6.26 \\
(38.68) \\
\end{array}$ & $\begin{array}{c}5.32 \\
(27.88) \\
\end{array}$ & $\begin{array}{c}5.62 \\
(31.12) \\
\end{array}$ & $\begin{array}{c}5.93 \\
(34.69) \\
\end{array}$ & $\begin{array}{c}6.03 \\
(35.93) \\
\end{array}$ & $\begin{array}{c}4.32 \\
(18.17) \\
\end{array}$ & \begin{tabular}{|c|}
3.41 \\
$(11.16)$ \\
\end{tabular} & $\begin{array}{c}3.61 \\
(12.59) \\
\end{array}$ & \begin{tabular}{|c|}
3.84 \\
$(14.45)$ \\
\end{tabular} & $\begin{array}{c}3.96 \\
(15.21) \\
\end{array}$ \\
\hline $\mathrm{T}_{2}$ - Quizalofop ethyl 5\% @ $75 \mathrm{~g}$ a.i./ha. & $\begin{array}{c}6.25 \\
(38.54) \\
\end{array}$ & \begin{tabular}{|c|}
5.14 \\
$(26.02)$ \\
\end{tabular} & $\begin{array}{c}5.54 \\
(30.33) \\
\end{array}$ & \begin{tabular}{|c|}
5.86 \\
$(33.88)$ \\
\end{tabular} & $\begin{array}{c}5.93 \\
(34.72) \\
\end{array}$ & $\begin{array}{c}4.50 \\
(19.80) \\
\end{array}$ & \begin{tabular}{|c|}
3.35 \\
$(10.74)$ \\
\end{tabular} & $\begin{array}{c}3.57 \\
(12.25) \\
\end{array}$ & \begin{tabular}{|c|}
3.78 \\
$(13.82)$ \\
\end{tabular} & $\begin{array}{c}3.94 \\
(15.04) \\
\end{array}$ \\
\hline $\mathrm{T}_{3}$ - Imazethapyr 10\%@50 g a.i./ha. & $\begin{array}{c}6.04 \\
(36.07)\end{array}$ & $\begin{array}{c}4.18 \\
(17.10)\end{array}$ & $\begin{array}{c}4.50 \\
(19.85)\end{array}$ & $\begin{array}{c}4.96 \\
(24.19)\end{array}$ & $\begin{array}{c}5.10 \\
(25.51)\end{array}$ & $\begin{array}{c}4.36 \\
(18.57)\end{array}$ & \begin{tabular}{|c|}
2.88 \\
$(7.79)$ \\
\end{tabular} & $\begin{array}{c}3.20 \\
(9.75)\end{array}$ & $\begin{array}{c}3.35 \\
(10.82) \\
\end{array}$ & $\begin{array}{c}3.62 \\
(12.67)\end{array}$ \\
\hline T4- Oxyflourfen@150g a.i./ha. & $\begin{array}{c}6.40 \\
(40.53) \\
\end{array}$ & \begin{tabular}{|c|}
4.09 \\
$(16.30)$ \\
\end{tabular} & $\begin{array}{c}4.40 \\
(18.93) \\
\end{array}$ & $\begin{array}{c}4.75 \\
(22.21) \\
\end{array}$ & $\begin{array}{c}4.86 \\
(23.17) \\
\end{array}$ & $\begin{array}{c}4.53 \\
(20.03) \\
\end{array}$ & \begin{tabular}{|c|}
2.83 \\
$(7.54)$ \\
\end{tabular} & \begin{tabular}{|c|}
3.13 \\
$(9.30)$ \\
\end{tabular} & \begin{tabular}{|c|}
3.30 \\
$(10.40)$ \\
\end{tabular} & $\begin{array}{c}3.51 \\
(12.12) \\
\end{array}$ \\
\hline $\begin{array}{c}\text { T5 - Imazethapyr 35\% + Imazomox 35\% @ } 40 \mathrm{~g} \\
\text { a.i./ha. }\end{array}$ & $\begin{array}{c}6.29 \\
(39.11)\end{array}$ & $\begin{array}{c}5.37 \\
(28.58)\end{array}$ & $\begin{array}{c}5.67 \\
(31.73) \\
\end{array}$ & $\begin{array}{c}5.83 \\
(33.52) \\
\end{array}$ & $\begin{array}{c}5.91 \\
(34.44)\end{array}$ & $\begin{array}{c}4.50 \\
(19.82) \\
\end{array}$ & \begin{tabular}{|c|}
3.32 \\
$(10.59)$ \\
\end{tabular} & $\begin{array}{c}3.52 \\
(12.03) \\
\end{array}$ & \begin{tabular}{|c|}
3.73 \\
$(13.49)$ \\
\end{tabular} & $\begin{array}{c}3.91 \\
(14.84) \\
\end{array}$ \\
\hline $\begin{array}{c}\text { T6 - Imazethapyr 35\% + Imazomox 35\% @ } 60 \mathrm{~g} \\
\text { a.i./ha. }\end{array}$ & $\begin{array}{c}6.18 \\
(37.68)\end{array}$ & $\begin{array}{c}5.26 \\
(27.25)\end{array}$ & $\begin{array}{c}5.44 \\
(29.19)\end{array}$ & $\begin{array}{c}5.69 \\
(31.90)\end{array}$ & $\begin{array}{c}5.78 \\
(32.90)\end{array}$ & $\begin{array}{c}4.28 \\
(17.80)\end{array}$ & \begin{tabular}{|c|}
3.28 \\
$(10.31)$ \\
\end{tabular} & $\begin{array}{c}3.47 \\
(11.63)\end{array}$ & $\begin{array}{c}3.71 \\
(13.28) \\
\end{array}$ & $\begin{array}{c}3.85 \\
(14.38) \\
\end{array}$ \\
\hline $\begin{array}{c}\mathrm{T}_{7} \text { - Clodinafop propargyl + Na-aciflurofen } 16.5 \% \\
@ 300 \mathrm{~g} \text { a.i./ha. } \\
\end{array}$ & $\begin{array}{c}6.04 \\
(35.97) \\
\end{array}$ & $\begin{array}{c}4.49 \\
(19.76) \\
\end{array}$ & $\begin{array}{c}4.85 \\
(23.05)\end{array}$ & $\begin{array}{c}5.17 \\
(26.28) \\
\end{array}$ & $\begin{array}{c}5.29 \\
(27.50)\end{array}$ & $\begin{array}{c}4.54 \\
(20.17) \\
\end{array}$ & \begin{tabular}{|c|}
3.08 \\
$(8.97)$ \\
\end{tabular} & $\begin{array}{c}3.35 \\
(10.79) \\
\end{array}$ & $\begin{array}{c}3.48 \\
(11.77) \\
\end{array}$ & $\begin{array}{c}3.66 \\
(13.17) \\
\end{array}$ \\
\hline $\begin{array}{c}\mathrm{T}_{8} \text { - Clodinafop propargyl }+\mathrm{Na} \text { aciflurofen } 16.5 \% \\
\text { @ 500 g a.i./ha. } \\
\end{array}$ & $\begin{array}{c}5.99 \\
(35.44)\end{array}$ & \begin{tabular}{|c|}
4.38 \\
$(18.74)$ \\
\end{tabular} & $\begin{array}{c}4.78 \\
(22.38) \\
\end{array}$ & $\begin{array}{c}5.14 \\
(25.97) \\
\end{array}$ & $\begin{array}{c}5.22 \\
(26.77) \\
\end{array}$ & $\begin{array}{c}4.39 \\
(18.82) \\
\end{array}$ & \begin{tabular}{|c|}
3.03 \\
$(8.70)$ \\
\end{tabular} & $\begin{array}{c}3.28 \\
(10.28) \\
\end{array}$ & $\begin{array}{c}3.46 \\
(11.49) \\
\end{array}$ & $\begin{array}{c}3.61 \\
(12.59) \\
\end{array}$ \\
\hline T9.Propaquizafop 10\%@100 g a.i./ha. & $\begin{array}{c}6.19 \\
(37.86)\end{array}$ & $\begin{array}{c}4.87 \\
(23.29)\end{array}$ & $\begin{array}{c}5.07 \\
(25.27)\end{array}$ & $\begin{array}{c}5.35 \\
(28.19) \\
\end{array}$ & $\begin{array}{c}5.42 \\
(28.89)\end{array}$ & $\begin{array}{c}4.30 \\
(18.03) \\
\end{array}$ & \begin{tabular}{|c|}
3.13 \\
$(9.51)$ \\
\end{tabular} & $\begin{array}{c}3.42 \\
(11.19)\end{array}$ & $\begin{array}{c}3.64 \\
(12.73) \\
\end{array}$ & $\begin{array}{c}3.84 \\
(14.23) \\
\end{array}$ \\
\hline $\mathrm{T}_{10}-$ Two hand weeding at 30 and 50 DAS. & $\begin{array}{c}6.17 \\
(37.64)\end{array}$ & $\begin{array}{c}3.66 \\
(13.00)\end{array}$ & $\begin{array}{c}4.15 \\
(16.78) \\
\end{array}$ & $\begin{array}{c}4.56 \\
(20.36) \\
\end{array}$ & \begin{tabular}{|c|}
4.79 \\
$(22.51)$ \\
\end{tabular} & $\begin{array}{c}4.49 \\
(19.65) \\
\end{array}$ & \begin{tabular}{|c|}
2.68 \\
$(6.74)$ \\
\end{tabular} & $\begin{array}{c}3.00 \\
(8.51) \\
\end{array}$ & \begin{tabular}{|c|}
3.15 \\
$(9.45)$ \\
\end{tabular} & $\begin{array}{c}3.39 \\
(11.10) \\
\end{array}$ \\
\hline $\mathrm{T}_{11}$ - Weedy-check & $\begin{array}{c}6.20 \\
(38.09) \\
\end{array}$ & \begin{tabular}{|c|}
8.27 \\
$(67.89)$ \\
\end{tabular} & $\begin{array}{c}9.35 \\
(86.95) \\
\end{array}$ & \begin{tabular}{|c|}
10.21 \\
$(103.78)$ \\
\end{tabular} & \begin{tabular}{|c|}
11.11 \\
$(122.94)$ \\
\end{tabular} & $\begin{array}{c}4.43 \\
(19.14) \\
\end{array}$ & \begin{tabular}{|c|}
6.13 \\
$(37.10)$ \\
\end{tabular} & \begin{tabular}{|c|}
7.04 \\
$(49.16)$ \\
\end{tabular} & \begin{tabular}{|c|}
8.13 \\
$(65.56)$ \\
\end{tabular} & $\begin{array}{c}8.79 \\
(76.78) \\
\end{array}$ \\
\hline $\mathrm{SE}(\mathrm{M}) \pm$ & 0.12 & 0.18 & 0.14 & 0.16 & 0.13 & 0.12 & 0.12 & 0.10 & 0.11 & 0.14 \\
\hline $\mathrm{CD} \mathrm{P}=0.05$ & NS & 0.55 & 0.41 & 0.46 & 0.40 & NS & 0.35 & 0.30 & 0.31 & 0.40 \\
\hline
\end{tabular}

Figures in parenthesis are original values

Table 2: Crop phytotoxicity score, weed control efficiency (\%) and weed index (\%) as influenced by weed control treatments in chickpea

\begin{tabular}{|c|c|c|c|c|c|c|c|}
\hline \multirow[b]{2}{*}{ Treatments } & \multicolumn{2}{|r|}{ Crop phytotoxicity visual rating score } & \multicolumn{4}{|c|}{ Weed control efficiency (\%) } & \multirow[b]{2}{*}{$\begin{array}{c}\text { Weed index } \\
(\%)\end{array}$} \\
\hline & Rate & Effect on crop & \begin{tabular}{|c|}
40 \\
DAS
\end{tabular} & $\begin{array}{c}\text { 60 } \\
\text { DAS }\end{array}$ & $\begin{array}{c}\text { 80 } \\
\text { DAS }\end{array}$ & $\begin{array}{c}\text { At } \\
\text { harvest }\end{array}$ & \\
\hline $\mathrm{T}_{1}$ - Quizalofop ethyl 5\% @ 50 g a.i./ha. & 0 & No injury, normal & 69.92 & 74.18 & 77.99 & 80.21 & 23.44 \\
\hline $\mathrm{T}_{2}$ - Quizalofop ethyl 5\% @ $75 \mathrm{~g}$ a.i./ha. & 0 & No injury, normal & 71.02 & 75.12 & 78.94 & 80.43 & 21.69 \\
\hline $\mathrm{T}_{3}$ - Imazethapyr 10\% @ 50 g a.i./ha. & 2 & Some stand loss, stunting or discoloration. & 78.94 & 80.25 & 83.51 & 83.53 & 9.10 \\
\hline T4 - Oxyflourfen @ 150 g a.i./ha. & 3 & Moderate injury, recovery is possible. & 79.72 & 81.13 & 84.15 & 84.31 & 5.07 \\
\hline $\begin{array}{c}\mathrm{T}_{5} \text { - Imazethapyr 35\% + Imazomox 35\% @ } \\
40 \text { g a.i./ha. }\end{array}$ & 3 & Moderate injury, recovery is possible. & 71.47 & 75.75 & 79.45 & 80.70 & 19.23 \\
\hline $\begin{array}{c}\mathrm{T}_{6}-\text { Imazethapyr } 35 \%+\text { Imazomox } 35 \% @ 60 \\
\text { g a.i./ha. }\end{array}$ & 3 & Moderate injury, recovery is possible. & 72.25 & 76.54 & 79.74 & 81.31 & 15.71 \\
\hline $\begin{array}{c}\mathrm{T}_{7} \text { - Clodinafop propargyl + Na-aciflurofen } \\
16.5 \% \text { @ } 300 \mathrm{~g} \text { a.i./ha. }\end{array}$ & 6 & Near sever injury, no recovery possible & 75.79 & 78.22 & 82.08 & 82.93 & 25.19 \\
\hline $\begin{array}{c}\mathrm{T}_{8} \text { - Clodinafop propargyl }+\mathrm{Na} \text { aciflurofen } \\
16.5 \% \text { @ } 500 \mathrm{~g} \text { a.i./ha. }\end{array}$ & 7 & Severe injury, stand loss surviving. & 76.50 & 79.15 & 82.48 & 83.66 & 26.67 \\
\hline T9-Propaquizafop 10\% @ $100 \mathrm{~g}$ a.i./ha. & 2 & $\begin{array}{c}\text { Some stand loss, stunting or } \\
\text { discolouration. }\end{array}$ & 74.73 & 77.24 & 80.59 & 81.48 & 11.19 \\
\hline $\mathrm{T}_{10}-$ Two hand weeding at 30 and 50 DAS. & 0 & Normal & 81.99 & 82.66 & 85.58 & 85.52 & - \\
\hline $\mathrm{T}_{11}-$ Weedy-check & 0 & Normal & - & - & - & - & 45.90 \\
\hline $\mathrm{SE}(\mathrm{M}) \pm$ & & - & - & - & - & - & - \\
\hline $\mathrm{CD} P=0.05$ & & - & - & - & - & - & - \\
\hline
\end{tabular}


Table 3: Growth, Yield attributes and grain yield ( $\mathrm{Kg} / \mathrm{ha})$ of chickpea as influenced by weed control treatments

\begin{tabular}{|c|c|c|c|c|c|c|c|c|c|c|}
\hline Treatments & \begin{tabular}{|c|} 
Plant \\
height \\
$(\mathrm{cm})$
\end{tabular} & $\begin{array}{c}\text { Plant dry } \\
\text { matter at } \\
\text { harvest (g) }\end{array}$ & $\begin{array}{c}\text { Number } \\
\text { of pods } \\
\text { /plant }\end{array}$ & $\begin{array}{c}\text { Seed } \\
\text { weight } \\
\text { /plant }(\mathrm{gm})\end{array}$ & \begin{tabular}{|c|} 
Seed \\
Index \\
(gm) \\
\end{tabular} & \begin{tabular}{|c|}
$\begin{array}{c}\text { Grain } \\
\text { yield } \\
\text { (Kg/ha) }\end{array}$ \\
\end{tabular} & $\begin{array}{c}\text { Harvest } \\
\text { Index } \\
(\%)\end{array}$ & $\begin{array}{l}\text { GMR } \\
\text { (Rs./ha.) }\end{array}$ & $\begin{array}{l}\text { NMR } \\
\text { (Rs./ha. }\end{array}$ & $\begin{array}{l}\text { B:C } \\
\text { ratio }\end{array}$ \\
\hline $\mathrm{T}_{1}$ - Quizalofop ethyl 5\% @ $50 \mathrm{~g}$ a.i./ha. & 43.72 & 17.17 & 41.79 & 9.17 & 21.84 & 1589 & 40.85 & 71723 & 41951 & 2.41 \\
\hline $\mathrm{T}_{2}$ - Quizalofop ethyl 5\% @ $75 \mathrm{~g}$ a.i./ha. & 44.19 & 17.50 & 42.55 & 9.29 & 21.22 & 1626 & 41.08 & 73367 & 42764 & 2.40 \\
\hline $\mathrm{T}_{3}$ - Imazethapyr 10\% @ 50 g a.i./ha. & 47.79 & 19.55 & 48.47 & 10.78 & 22.23 & 1886 & 41.62 & 84944 & 55403 & 2.87 \\
\hline T $\mathrm{T}_{4}$ - Oxyflourfen @ $150 \mathrm{~g}$ a.i./ha. & 48.40 & 19.95 & 49.51 & 11.36 & 22.40 & 1965 & 42.35 & 88358 & 58884 & 3.00 \\
\hline $\begin{array}{c}\text { T5 - Imazethapyr 35\% + Imazomox 35\% @ } 40 \mathrm{~g} \\
\text { a.i./ha. }\end{array}$ & 44.45 & 17.97 & 43.07 & 9.40 & 21.93 & 1675 & 39.30 & 75958 & 46742 & 2.60 \\
\hline $\begin{array}{c}\text { T6 - Imazethapyr 35\% + Imazomox 35\% @ } 60 \mathrm{~g} \\
\text { a.i./ha. }\end{array}$ & 44.93 & 18.21 & 43.50 & 9.41 & 22.58 & 1746 & 41.31 & 78734 & 49018 & 2.65 \\
\hline $\begin{array}{c}\mathrm{T}_{7} \text { - Clodinafop propargyl + Na-aciflurofen } 16.5 \% \\
\text { @ } 300 \mathrm{~g} \text { a.i./ha. }\end{array}$ & 38.60 & 15.77 & 37.93 & 7.61 & 21.29 & 1548 & 40.68 & 69921 & 41081 & 2.42 \\
\hline $\begin{array}{c}\text { T8- Clodinafop propargyl + Na aciflurofen } 16.5 \% \\
\text { @ 500 g a.i./ha. } \\
\end{array}$ & 37.74 & 15.42 & 35.17 & 7.25 & 22.13 & 1517 & 40.69 & 68534 & 39355 & 2.35 \\
\hline T9-Propaquizafop 10\% @ 100 g a.i./ha. & 45.43 & 18.39 & 45.00 & 9.60 & 22.41 & 1844 & 41.19 & 83170 & 52888 & 2.74 \\
\hline$T_{10}-$ Two hand weeding at 30 and 50 DAS. & 51.82 & 21.17 & 50.53 & 11.65 & 22.62 & 2073 & 42.79 & 93120 & 59679 & 2.78 \\
\hline $\mathrm{T}_{11}-$ Weedy-check & 36.56 & 11.62 & 31.48 & 6.37 & 21.07 & 1124 & 37.87 & 51171 & 23779 & 1.87 \\
\hline $\mathrm{SE}(\mathrm{m}) \pm$ & 1.79 & 0.89 & 1.86 & 0.56 & 0.69 & 76 & - & 3278 & 3278 & - \\
\hline $\mathrm{CD} P=0.05$ & 5.27 & 2.61 & 5.48 & 1.64 & NS & 224 & - & 9672 & 9672 & - \\
\hline
\end{tabular}

\section{References}

1. Alaeldin M, Elhassana PH, Khalifa KA, Hassan SA. Efficiency and economic feasibility of manual and chemical weed control in faba bean. Nile Journal for Agricultural Sciences. 2016; 1:49-63.

2. Chaudhary BM, Patel JJ, Delvadio DR. Effect of weed management practices and seed rates on weeds and yield of chickpea. Ind. J. Weed Sci. 2005; 37:271-72.

3. Chavada JN, Patel SP, Patel SB, Panchal PP, Patel GN. Weed management in chickpea (Cicer arietinum) under north gujarat conditions. International Journal of Science 2278-3687 (O) environment and Technology, 2017, 6(3).

4. Ghosheh HZ, El-Shatnawi MK. Broadleaf weed control in chickpeas (Cicer arietinum), Faba beans (Vicia faba) and Lentils (Lens culinaris). Acta Agronomica Hungarica. 2003; 51(4):437-444.

5. Gupta VB, Singh N, Kumar JM, Singh Jamwal BS. Effect of imazethapyr on weed control and yield in chickpea under kandi belt of low altitude sub-tropical zone of Jammu. Madras Agri. J. 2012; 99:81-86.

6. Kachhadiya SP, Sawaliya JJ, Bhula VB, Pansuriya AG, Sawaliya SG. Evaluation of new herbicides for weed management in chickpea legume. Res. 2009; (32)(4):293297

7. Lyon DJ, Wilson RG. Chemical weed control in dryland and irrigated chickpea. Agronomy, EDP sciences, 2005, 123-127.

8. Maity SK, Mukherjee PK. Effect of brown manuring on grain yield and nutrient use efficiency in dry direct seeded kharif rice. Indian Journal of Weed Science. 2011; 43:61-66

9. Marwat KB, Hashim S, Hassan G. Chemical weed control efficiency in potato (SolanumtuberosumL.) under agro-climatic conditions of Peshawar, Pakistan. Pakistan J. Weed Sci. Res. 2003; 9(1-2):105-110.

10. Muhammad N, Sattar A, Ashiq M, Ahmad I. Efficacy of pre and post emergence herbicides to control weeds in chickpea (Cicer arietinum). Pak. J Weed Sci. Res. 2011; 17(1):17-24.

11. Mukherjee RK, Datta SK. Effect different weed control practices in chickpea. Weed Res. 2007; 33:1-8.

12. Patel, BD. and Patel VJ. Effect of fertilizers and weed management practices on weed control in chickpea.
Under the middle Gujarat condition. Indian J of crop Sci. 2006; 1(1-2):180-183.

13. Patel BD, Patel VJ, Meisuriya MI. Effect of FYM, molybdenum and weed management practices on weeds, yield attributes and yield of chickpea. Indian J Weed Sci. 2006; 38(3 and 4):244-246.

14. Poonia TC, Pithia MS. Pre and post-emergence herbicides for weed management in chickpea. Indian Journal of Weed Science. 2013; 45(3):223-225

15. Rao VS. Principles of weed science II ${ }^{\text {nd }}$ Edn. Oxford and IBH publishing Co., New Delhi, 2000.

16. Ratnam MA, Rao S, Reddy TY. Integrated weed management in chickpea (Cicer arietinum L.). Indian $\mathrm{J}$ Weed Sci. 2011; 43(1 \& 2):70-72.

17. Reddy KM, Singh S, Kumar VP. Weed control in chickpea under dryland conditions. In competition with rice. Weed Res. 2008; 37:33-38.

18. Rupareliya VV, Chovatia PK, Vekariya SJ, Javiya PP. Effects of different pre and post emergences herbicide on growth, yield attributes, yield and quality of chickpea (Cicer arietinum). International Journal of Science, Environment and Technology. 2017; 6(4):2587-2593.

19. Sharma SK. Weed control in chickpea under dryland conditions. Haryana J. of Agronomy. 2005; 21(1):24-25.

20. Singh KR, Shukla DN Nirmal. Effect of biofertilizers, fertility level and weed management on weed growth and yield of late sown chickpea (Cicer arientium L.). Indian J Weed Sci. 2006; 76(9):561-563.

21. Singh G, Aggarwal N, Ram H. Efficacy of postemergence herbicide imazethapyr for weed management indifferent mungbean (Vigna radiata L.) cultivars. Indian J Agric. Sci. 2017; 84(4):540-543.

22. Yusefi AR, Alizadeh HM. Broad leaf weed control in chickpea with pre and post-emergence herbicides. Research on crops. 2007; 8(3):560-564. 